\title{
Ethnographic Studies on the Montenegrin Festive Costume as a National Symbol
}

\author{
Sofiya Zahova
}

\begin{abstract}
Balkan Ethnology Department, Institute of Ethnology and Folklore Studies with Ethnographic Museum, Bulgarian Academy of Sciences szahova@yahoo.com
\end{abstract}

The Montenegrin official national costume (known also as Njegoševa nošnja or the Costume of Njegos), and the Montenegrin hat as an integral part of it, are considered to be an important ethno-cultural marker for Montenegrins. They are the subject of special attention from the very first ethnographic records on Montenegro, and later in Yugoslav ethnology. Nowadays, the interpretation of national symbols of ethnic belonging related to the Montenegrin costume presents the two major scientific concepts of the genesis and identity of Montenegrins: one a pro-Serbian and the other a Montenegrin. This paper provides both an overview and an analysis of the ethnographic and historic scientific works on the Montenegrin costume, which view the costume as a marker of ethnic identity and national belongingness and from which two clear opposing positions can be identified. The dominating position (and chronologically the earliest) claims that the Montenegrin people are part of the Serbian national corpus, while the other states that the Montenegrins have had an autonomous and distinct historical and ethno-cultural development since medieval times. Since national costumes are usually seen as means to affirm national identity and are in the "register" of national symbols, the article examines the scientific publications on the symbolic meanings of the Montenegrin costume in light of the wider context of interpretation of Montenegrin history and culture and their elements as ethno-cultural markers for Serbian or Montenegrin identity amongst the Montenegrin people.

Key words: Montenegro, national building, festive costume(s), Yugoslav ethnography

\section{Introduction}

The development of Montenegro can be rightfully described as a dynamic one in a similarly dynamic region. From the previous century up to now it has been undergoing major historical, political, and socio-cultural changes from a sovereign country uniting the South Slavs during the 20th century to an independent state in 2006 that is "civic, democratic, and ecological". ${ }^{1}$ Despite the changes, including the dynamics of identity of its population, ${ }^{2}$ a steady marker of the 
Montenegrin ethno-culture that could be rightfully called a symbol of Montenegro for both Montenegrins and for the "outsiders" (their neighbours and visitors) is the Montenegrin national costume the festive costume, also known in popular terms as golden dress (zlatno odjelo), the costume of Njegoš (Njegoševa nošnja), including the Montenegrin hat (Crnogorska kapa). The last appears to be the second most popular article of souvenir trade in today's Montenegro after the national flag. There is nothing new in the statement that a national costume has been incorporated in the "symbolic reservoir" of the national symbols. The dress is described as national, the folk costume and national clothing as a whole are often part of the cultural politics by which national consciousness and ethnic identification is maintained or (re)produced (Anderson 2006, Hobsbawm 2006). The national awakening processes in the Balkans were led by the intellectual elite, who recorded and promoted the cultural treasures of the people. Records of national clothing and costume were an object of a purposeful collection. Different descriptions of the Montenegrin costume have been recorded during the period from the second half of the 19th to the beginning of the 20th century, when the denoting and defining of the so-called "folk costume" and, consequentially, its scientific interpretation served the purpose of national emancipation for independence or for proclaiming the national consciousness of the people who wore it.

A century later, with the process of state development in Montenegro, the symbolic meaning of the costume and its scientific interpretations in light of the national consciousness of the Montenegrin people have not lost their importance. On the contrary, the development of the debate over Montenegrin independence at the end of 20th and beginning of the 21st century went hand in hand with the debate whether Montenegrins have enough cultural and historical reasons to be a state (i.e., whether they have the right to be a nation) as well as with disputes on the Montenegrin ethno-cultural phenomena as symbols of national (Serbian or Montenegrin) identity. In light of this debate, popular and scientific publications have been raising the issues of Montenegrins' identity, history, and culture as part of the issue whether they should be a separate and distinct state (for details see Pavlović 2003, Pavlović 2003a). Culture and history have become issues created and recreated by various groups and interests and the two competing versions on the 
Montenegrin national question underpin much of the political and scientific discourse. Ethno-national characteristics such as religion, history, family- and ethno-genesis, language, and others became issues for interpretation in the hands of two opposite positions: one stating that Montenegrin people are part of the Serbian national corpus, and this is proven by their (Serbian) language, religion, and consciousness and the opposing claim that Montenegrins form a separate nation with its distinct (from Serbian) culture, language, consciousness, and (state) history. Historical events, literature, and the official documentation of the Petrović dynasty (that ruled Montenegro from 1697 until 1918) are explored and analysed in order to demonstrate that the national consciousness of the population in the past legitimizes the same (consciousness) in the present.

The national costume, known also as Njegoševa nošnja, was an object of many descriptions since the very first ethnographic descriptions of Montenegro. It is a men's festive costume, believed to have been officially introduced by Petar II Petrovic Njegoš (1782-1830) ${ }^{3}$ himself and it was the uniform for the Montenegrin army and officials until 1910. It has also been a subject of ongoing scientific debate concerning its historical appearance, genesis, influence, dissemination, usage, and symbolism. The historical importance of the costume, used by brave Montenegrin warriors in battle, as well as the symbolic meaning of the Montenegrin hat as a substitute for the men's dignity and honour, give additional reasons for keeping it and giving it high national value, apart from its aesthetics outlook and rich embroidery. It is an important marker for the people and for scientists because it is one of the very first attributes related to the material culture of the Montenegrins, but much more because it is seen as being related to the historical development and important facts and figures of Montenegrin history and culture. The Montenegrin national costume did not end up in the museums and ethnographic collections as an item with souvenir value. Even during the time of modernization and industrialization throughout 20th century many Montenegrins from the older generation kept parts of the costume in order to be buried in the traditional way or to be used on festive occasions in the family cycle.

Nowadays the tradition of wearing a partial or complete costume is seeing a rebirth and is cast into new light. During the first half 
of 2006, when Montenegrins were preparing to vote on the issue of independence, Montenegrin cities hosted many meetings and demonstration for and against state independence. The so-called Yes and No block were easily distinguished by their mottos, posters, speeches, and national symbols such as anthem, coat of arms, and flags (Montenegrin and Yugoslav respectively). But the proud men who had different flags and slogans that clashed with one another had completely identical traditional festive costumes. This picture is symptomatic for the whole Montenegrin traditional culture, which is defined as ethno-national since it is about the issues of two competing consciousnesses of one people and two national identities of the same population (Pavlović 2003, Bieber 2003, Malesevic, Uzelac 2007).

In this context, the political discourse and politics of identity became correlated with the scientific publications in the field of ethnography and culture. Ethnicity, political process, and scientific discourse are closely interconnected in the region (Halpern \& Hammel 1969, Pišev 2009). As Halpern and Hammel point out in their analysis on the interrelations between Yugoslav social science and other aspects of Yugoslav culture, there is a special focus on ethnology of the East and this is an intellectual justification of the independent political existence valid for Yugoslav ethnology and it comes straight from of the Karadžić tradition (Halpern \& Hammel 1969: 17-18). The scientific interpretations of the genesis, meaning, and development of the Montenegrin festive costume illustrate this interconnection per se. As a sufficient part of the substance of ethnicity in Montenegro and as a component of "the national character" for the ethnographic descriptions as a whole, the issue of the meaning and genesis of the costume is disputable in contemporary ethnology research on Montenegro. Exactly because of its significance and historical development, the festive costume opened up an ongoing (although a comparatively limited) scientific discussion in ethnology. I review and analyse the scientific arguments used by the two opposing theses in chronological perspective. I'll apply the method of analysis to ethno-symbolic national discourses and its relation to the politics of identity. The article analyses sources from the political and everyday discourses that participated in my field research in Montenegro, implemented as part of a $\mathrm{PhD}$ thesis "Dynamics of Identity in Montenegro" in 2008-2009. 


\section{One object of study, two interpretations}

The traditional costume, known as Montenegrin has the following parts: white shirt (košulja), wide blue trousers (dimii), white over-knee socks, red overcoat (džamadan) with or without sleeves, gunja jacket in light blue colour, or dark green dolama jacket. Over the gunja or dolama jacket a red jelek or red dušanka jelek is put, richly embodied with gold ornamentation (Mrvaljević 2006). There is also the leather belt pojas (silav), around which a long piece of cloth is tied, most often red in colour (trombolos). The main parts of the costume, with which other garments were combined, are: the red silk baize $d \check{z}$ amadan jacket, wide blue trousers and white over-knee socks. Dušanka and dolama jackets have a design with hanging sleeves, while dušanka, džamadan, djecerma and jelek jackets are characterized by their rich golden embroidery (Mrvaljević 2006). The colours are: red (token ornaments, džamadan jacket, jecerma jackets, jelek jackets, dušanka jackets), blue (trousers, jaketa jackets), green (dolama jackets) and white (gunja overcoat, over-knee-socks, knee-socks, women's koret jackets, silk shirts and skirts). These three colours are predominant and characteristic of the men's festive costume. Up to the present time, the Montenegrin costume remains one of the most popular ethno-identifying markers of Montenegro.

Obligatory parts of the costume are the hat and the guns. The hat is in the shape of a small flat cylinder and its bottom red part is called tepelak, while its brim is black and is called derevija. A part of the bottom is decorated with five golden nits in the shape if semi-circle which has a centre with certain embroidery. During Njegos' time, his associates would put the initials of their tribal names (nahija) on top of their hats. During the reign of Prince Danilo and King Nikola, these were replaced with the king's initials (D.I., N.I.), a cross and four fireplaces, as well as stars with five or six points, or the initials of the owner of the hat himself. The belt has guns, without which a man in Montenegro would be considered naked. Usually these include a couple of guns, a jatagan knife, and a long rifle (džeferedar, arnautka) on the back. A variety of Montenegrin costumes presenting this type can be seen online. ${ }^{4}$

While the traditional female costume varies widely from one region of Montenegro to another, the costume known as festive Montene- 
grin is fixed since during the rule of Njegoš and afterwards it became the official uniform of the governing bodies' officials in civil institutions and the army (Istorija Crne Gore 1975: 158-159). It was also accepted by lay-people and was a uniform of honour signifying the identity of a warrior and supporter of the ruler. All men that had the financial means bought or ordered the Montenegrin costume which they wore when going to war, weddings and family gatherings, e.g. on all the main festive and official occasions particular to the culture. The high cost of the elements of the costume prevented its mass dissemination (Mrvaljević 2006: 82-83) but the hat was a must for men within traditional Montenegrin society.

$* * *$

Based on the field records and statements of the school and CvijićErdeljanović (Erdeljanović 1907, 1911; Djonović 1935; Šobajć 1923; Nakičenović 1982), information published in particular articles devoted to the folk costumes in Yugoslavia or on the Montenegrin costume (Durković-Jakšić 1953: 105-106; Radojevic 1969; Vlahović 1953: 151; Vukmanović 1953), the first interpretation of the existence and development of the costume dominant in Yugoslav ethnography after WWII was that the costume appeared comparatively late (sometime in the 19th century) parallel to the Serbian national project of Petar I (reigned 1782-1830) and Petar II Njegos (reigned 1830-1851) and that its meaning and genesis should be searched for in influences outside Old Montenegro (Barjaktarović 1979, Barjaktarović 1987, Vlahović 1995). This influence is historically bound to Serbian ethnic tradition and the embodiment of national symbols of the Serbian national idea - the Kosovo myth and the wish for the rebirth of the great Serbian state. In dispute, a few Montenegrin ethnographers in the 1960s and beginning of the 1970s trace the development of the Montenegrin costume back to medieval times and refer it to an older dynasty ruling Montenegro (Dragićević 1962, Radulović 1976). This was when the intellectual climate in Yugoslavia stimulated the development of research at a national level on the basis of archival visual and written sources. This scientific interpretation was further developed in Montenegro in the 1990s and in the new millennia (Mrvaljevic 2006) and has also become common for the new pro-Montenegrin school of history in 
Montenegro (Enciklopedija Crne Gore 1996, Istorijski Leksikon Crne Gore 2006). Through the 1960s to the 1980s the discussion itself did not touch upon the issue of the national meaning of the costume, reflecting the politics of that time (to lightly discuss national issues opposing Serbian and Montenegrin people) and, thus, inheriting the ambiguity of Montenegrin identity. After 2000, when the two concepts about the political development of Montenegro were clear (one for independent state and the other for union with Serbia), the discussion went into the field of ethnic and national identification and stood behind the costume. Petar Vlahović (Vlahović 1995) presented a widely distributed publication (of the English version of the article) on the Serbian national view and Zorica Mrvaljevic put the development of the national costume in light of the new official Montenegrin history (Mrvaljević 2006). The ethnology field research undertaken by me during 2009 in different parts of Montenegro on a variety of topics related to the issues of national belonging and ethnic identity showed that the discussion went far beyond scientific interest as many people use the outlook and symbolism of the Montenegrin costume in support of a Serbian or Montenegrin national consciousness.

Many of the scientific topics in the Yugoslav ethnology developed along a path that had been drawn by Vuk Karadžić (Halpern, Hammel 1969: 20) and that of the national costume is no exception. The first detailed, written ethnographic description of the traditional male costume was published in 1836 in Vienna as part of "Montenegro and Boka Kotorska" (Karadžić 1922). Afterwards many other descriptions by Western (Delari 2003; Schwarz 1876; Stivenson 2001; Svatek 2000; Mantegaca 2001) as well as regional writers (Medaković 1860, Nenadović 1929, Nenadović 1950) dealt with the official and every day costumes of Montenegrins, as well as the clothes and guns characteristics for the Montenegrin citizen. Despite the fact that the ethnographic research on Montenegro pays limited attention to the so-called material culture and is rather concentrated on research of the migration and demographic processes among the Montenegrin tribes and their traditional socio-normative culture, the Montenegrin men's costume has its particular place in Yugoslav ethnography (Vukmanović 1953, Radojević, 1969, Vlahović 1953) known also as Crnogorska svečana nošnja, Njegoševa nošnja or zlatno odjelo (Durković-Jakšić 1953, Vukmanović 1952). This 
research is based on ethnographic notes of travellers and publicists from Western and Central Europe who visited Montenegro at the end of 18th and throughout the whole 19th century. It is based on data presented in ethnographic research conducted in separate regions or tribes that were characteristic for the school of Anthropogeography recording the period of traditional culture in Montenegro (Erdeljanović 1920, Erdeljanović 1978, Rovinski 1998 , etc.) and also on visual sources. This phenomenon is not an exception from the different descriptions of folk costumes in general which appeared from the second half of the 19th to the beginning of the 20th century, and along with their scientific interpretation served the purpose of national emancipation and independence of the Balkan people (Kale 2009: 96).

The first scientific descriptions of the Montenegrin costume as part of the material culture and clothing find their place in the rich ethnography on tribes and regions (nahijas) in Montenegro written by members of the Cvijić-Erdeljanović school. These works proceed from the basic postulates of the Karadžic tradition and the thesis that the ethnic groups in the territory of Montenegro are Serbs of Orthodox faith. The (Serbian) ethnicity was an existing implicit dimension in all other works of the ethnographers conducting research in Montenegro. The postulate about the Serbian folk mentality of the Montenegrins as revealed in their ethno-culture and historical development was considered by default. The approach had not been altered afterwards in later works devoted to Yugoslav national costume. Thus, the Serbian and Yugoslav ethnology as a whole considered the Montenegrin costume to exist since the time of rule of Petar II Petrović Njegoš as one segment of his national project for unification of folk clothing with the aims to symbolize the state encompassing all parts of Old Montenegro and the Bay of Kotor. This unifying symbolism could be attained by incorporating elements from both the peoples' and leaders' costumes from each part of Montenegro. ${ }^{5}$ These works did not pay special interest to arguing what the national consciousness of the Montenegrins is since they were based on the postulate that Montenegro is part of the Serbian state, nation, church, and language. Therefore, they implied the understanding typical for the social sciences that Serbian mentality is part of the ethno-culture of the Montenegrins. The second statement that dominates Serbian ethnology is that the 
Montenegrin costume and its hat embody all important national symbols of the Serbian people and their restless struggle against the Turks. These works are written in a different contexts: the central issue is the development of the Montenegrin republic and nation, and in this way we find that they do argue over the meaning and historic development of the costume as proof that Montenegrins subscribed to the Serbian national myths, narratives, history, and consciousness. This argument is employed in the ethnological works of one of the most prominent ethnologists of Montenegrin origin who worked within the framework of the Serbian Academy of Sciences and Arts on different topics of Montenegrin and Serbian ethnography throughout the second half of the 20th century: Petar Vlahović and Mirko Barjaktarović. Their works were written in a time when the postulate of Serbian ethnicity in Montenegro was shaken and a central part of the works dealt with the historical development of the costume and hat in the context of the Serbian myth of Kosovo and national consciousness of the Petrović dynasty and the Montenegrin people (Vlahović 1978, Vlahović 1990, Vlahović 1995, Barjaktarović 1979). The works employ a wider framework of interpretation of the ethnic origin of the Montenegrins and the thesis that Montenegrin folk culture is part of the Serbian national corpus. According to them, Montenegrins are territorial ethnographic definition of a national belonging, which is Serbian, and the development and design of the Montenegrin costume and its hat are both a result and a proof of this fact.

These conclusions contrasted with those of two ethnologists who based their research in cultural institution in Cetinje, the historical capital of Old Montenegro, and who share the statement that the development of the Montenegrin costume should be referred to periods before Njegoš, continuing a Montenegrin dynastic tradition from medieval times, which was influenced by the Serbian tradition as far as all medieval Balkan states and their aristocracy was influenced by Byzantium. Risto Dragićević (Dragićević 1962) first shared this view in 1962 and afterwards it was further developed and promoted by Zorica Radulović and Zorica Mrvaljević (Radulović 1976, Mrvaljević 1988). Today, in the context of its contribution to the development of the social sciences and humanities in independent Montenegro, the bi-lingual monographic work of Mrvaljavić "The National Costume of Montenegro" (2006) explicitly elevates 
the pro-Montenegrin concept for the early origin of the Montenegrin costume in the time of Zeta (first a principality within the Rascia ruled by Nemanjić dynasty and after 1356 as autonomous under the rule of Balšićes), which is considered the medieval state-predecessor of Montenegro (Rastoder 2003). Its continuation through the centuries was maintained since it was a symbol of Montenegrin state, independence and struggle.

\section{Montenegrin Costume as Serbian National Symbol}

Like many traditional Montenegrin cultural phenomena (e.g., house-hold traditions, architecture, spiritual beliefs, etc.), the costume was first described in detail by Vuk Karadžić. Since then, all the elements of Montenegrin culture in ethnographical and social sciences are implicitly considered to be Serbian since "Montenegrins are Slavs of the Serbian branch of the Greek [Orthodox] law" (Karadžić 1972: 4). The Montenegrin costume is interpreted as a symbol of the Serbian national spirit in Montenegro, which can be freely developed in Montenegro. A few years later, Ljubomir Nenadović (Nenadović, 1929), a secretary and a close friend of Njegoš, also provided descriptions of the Montenegrin costume as a Serbian symbol, worn as official dress by Njegoš himself and his officials upon visits to other countries or hosting diplomats in his palace. Nenadović claims that Njegoš had introduced the costume and made a better tapestry. He also re-tells the legend about the Montenegrin hat:

And all around the hat a black cloth is attached. And this is a sign of mourning for the fallen kingdom. On the bottom of the hat all is made from red cloth; a small spot on the cloth is circled with golden rails. This represents (the idea) how the Turk had suppressed everything, and only that small piece had been left; this is Montenegro. That is how many people think... these hats are really from very old times... Mostly the dead metropolitan had introduced them in Montenegro. (Nenadović 1929: 20-21)

During the period of rule of King Nikola I Petrović (1860-1918) visitors of Montenegro provided impressions of the costume and the interpretations among the Montenegrins recorded by the visitors 
themselves. Berhard Schwarz (1876) also describes the costume as Serbian and compares it with the three-coloured German flag. Viko Mantegaca (2001) writes that the Montenegrin costume and hat are symbols of Serbian Montenegro - the black colour (kant) of the hat is mourning for the Serbian fatherland, the red colour of the background is a symbol of the blood devoted to the independence, while the small golden semi-circles and the initials in it symbolize the small but independent Montenegro with its wild mountains in which Serbians had found shelter. The written records of the visitors, in fact, accounted a popular interpretation that existed at that time in Montenegro: many people there had seen the glorious times of the Serbian state as an example with which they identified. Apart from his writings, the field research of Andrija Jovićević (Jovićević 1903) and Venijamin Boroski (as quoted in Mrvaljević 2006) also record the costume and hat as symbols of the Serbian national idea and the Kosovo myth. According to Jovićević (Jovićević 1903: 56-58) the name dušanka is derived from the name of King Dušan, ${ }^{6}$ whose servants in the palace used to wear the same jacket. The folk version recorded most often by Jovicević interprets the black wrapper as a sign of grief for the once big (Serbian) Empire, the red colour as the bloody defeat at the Battle of Kosovo, and the five small stripes on the top represent the remains of the once greater Serbian realm. This version became increasingly popular amongst the common folk during the reign of Prince Danilo I Petrović-Njegoš (1697-1735).

In the school of Anthropogeography to which Jovićević belongs, the costume and dress, as well as all traditional culture segments are interpreted as Serbian, while their specifics are explained by different geographic and historical developments (tribes, social norms such as the blood feuds, etc.). For one of the most prominent characteristics of the Montenegrin spirit is the belief that Serbian heroes are their fore-fathers, the national morals and thought are inherited from times past and they became instincts of the individual and the people. The national idea for Serbian state and spirit has lived on with Montenegrins, since they all consider Miloš Obilici ${ }^{7}$ to be their spiritual ancestor and a measure for their deeds. The Serbian ethnic origin of the Montenegrins as part of the research on tribes' formations and peoples' migrations is a central issue for the school of Serbian/Yugoslavian ethnology at the end of 19th and beginning of the 20th century. Interpretations of historical sources and ar- 
chives from medieval times that are quoted as proof of the Serbian ethnic compositions of the Montenegrin's land and Serbian origins of the Montenegrins tribes are part of the Serbian and Yugoslav historiography, while for the ethnographers the Serbian ethnicity should be proved by their research on mythical and real origins of the tribes, brotherhoods, and families as well as by accounting the linguistic, religious, and other elements of the culture. This historiographical tradition believes that during the time of the Ottoman Empire on the Balkan Peninsula, Serbians had migrated towards lands of Old Montenegro difficult to access. That is why the Montenegrin tribes have a Serbian national consciousness connected to the tradition of the medieval Serbian state. Under the political circumstance of lacking (Serbian) statehood, Montenegrin tribal existence (as based on the older Slavic socio-political institutions) is viewed as a territory that had kept the tradition of the old Slavs' division in tribes over generations (Cvijić 1922, Erdeljanović 1920, Erdeljanović 1978). The characteristics of the Montenegrin culture are Serbian, while their particularities developed different than Serbia's due to different political and geographic conditions. For example, the warrior spirit has its expression in the gun cult while men in Serbia were forbidden to wear guns as Orthodox population in Ottoman Empire.

The Serbian national idea for renewal of medieval Kingdom and the Kosovo myth are memories of the "golden ages" (Smith 1996) and, as such, they have a special place in both Serbian historiography and folklore epic poetry and narratives. Typical phenomena of the ethno-culture are interpreted in such light and this is valid for the festive costume of Montenegro which is a symbol with value similar to the official flag, coat of arms, etc. The Petrović Dynasty rulers, therefore, who introduced the idea of renewal of the Serbian statehood and devotion of the Kosovo oath of renewing the state, should be directly related to all these symbols.

Keeping in mind this context of Serbian/Yugoslavian historiography, we should move on to works devoted to the Montenegrin costume and hat. While in the first half of the 20th century, the historiography paid attention to general works on ethnology of certain regions in Montenegro and their population (part of which was research on traditional culture), after WWII there is a growing interest in 
Montenegrin dress, costume, and hat. Miodrag Vlahović (within a wider overview on the hats in Yugoslavia [Vlahović 1953]) names Njegoš as the ruler who introduced the hat in Montenegro as part of his statehood project related to the Serbian national ideal. Jovan Vukmanović, a leading Montenegrin ethnographer, published an article that connected the festive Montenegrin costume directly to Njegoš (Vukmanović 1952), after whom he also names the festive costume (Njegoševa nošnja). The period of Njegoš's rule is believed to be the time when the golden Montenegrin costume was worn generally by all Montenegrins (Vukmanović 1952: 133). Being a national unifying dress, the costume was designed in a way similar to that of the ordinary Montenegrins, but more expensive (Vukmanović 1952: 138), and it was widely applied and promoted by Njegoš since it was "at the same time a national symbol" (Vukmanović 1952: 137-138).

The work of Vukmanović in the 1950s is devoted to describing the written and pictorial sources of the Montenegrin festive costume, while the works of Mirko Barjaktarović (Barjaktarović 1979, Barjaktarovic 1987) are explicitly related to placing Montenegrin history and culture within the framework of the Serbian national ideal. There are two crucial points in interpreting the genesis, meaning, and development of the official costume worn in Montenegro. The first point is that the festive Montenegrin costume and hat are not a genuine Montenegrin phenomena and do not reflect the costume worn in Old Montenegro but are hugely influenced by outside cultures and created from the top (worn first by Njegoš, rich leaders, and officials). The point is that they have a symbolic meaning containing some of the most important national symbols of the Serbs.

The first point is supported by the following arguments. The costume is very expensive and limited to a circle of people who could afford it. The buyers of the costume could only have been of the wealthier strata of society and it was not disseminated among lay-men (Barjaktarović 1979: 122). The second point (argued extensively) is that the national tradition of medieval Serbia is kept, according to the author, not in Old Montenegro but in the bay of Kotor, where sources from the 15th through 16th centuries testify that Montenegrins were buying clothes and goods from Kotor. Throughout its history, Old Montenegro has had different styles of dress and the 
new clothing was formed by the Montenegrins at the second half of 19 th century by borrowing (from Boka) and by changing what they had, and possibly borrowing from the neighbouring Turks or Montenegrins traveling to Istanbul (Barjaktarović 1979: 128). The two state-building rulers disseminated the costume as a national Serbian symbol. Petar I started changes in the state and it is possible that he started to wear the costume from Boka on purpose, but during the time of Petar I Njegoš and Petar II Njegoš, some parts of the costume were finally created, and some even had symbolic meaning at the time (Barjaktarović 1979: 126). Barjaktarović concludes that once Montenegro was finally independent during the time of Petar II Njegoš, it is possible that the costume was finally created and was intended as a national costume, and probably was thence disseminated outside Montenegro (Barjaktarović 1979: 129).

As far as the Serbian national idea is concerned, Barjaktarović states that during the same period national awakening took place in the region and Serbian intellectuals tried to create a Serbian national costume. It is not coincidental that the colours of the costume present the Serbian national flag - red džamadan, blue dimije, white dokolenice. These symbols fitted the politics of Njegoš (Barjaktarović 1979: 130-131) aimed at renewing the Serbian Kingdom, as well as the symbols embodied by the hat, since the hat signified the dignity of the man. The same notion of interpretation is stressed when interpreting the coat of arms of Montenegro (two-headed eagle). It is the coat of arms of Serbia, which was originally taken from the Greek insignia - a cross with four oscines that later also had an eagle. In Byzantium they are presented as four letters beta (B), while in Montenegro as the Cyrillic letter S and mean "Only the accord saves the Serb” (in Serbian Samo sloga Srbina spašava) (Barjaktarović 1979: 133).

Quoting the conclusions of Barjaktarović, the work of Petar Vlahović (Vlahović, Petar 1995), devoted to the Serbian origins of Montenegrins, continues this thesis more explicitly and presents an emanation of the point of view of Serbian historiography on the Montenegrin question, including interpretations of the Montenegrin festive costume as a symbol of Serbian identity and the national idea in Montenegro. The first part of Vlahović's study is devoted to documents proving that Montenegrins declared themselves as 
Serbs both historically and ethnically. The rule of the Petrović dynasty and particularly the time of Petar II Petrović Njegoš and King Nikola are seen as consequences of the deeds of Dositey Obradovic, a promoter of Slavic unity. They aimed at elaborating criteria for and initiating the promotion of Serbian national consciousness, since their authority arose from the authority developed in the times of the Nemanjić, Balšić, and Crnojević dynasties (Vlahović 1995). The author concludes that the Serbian ethnic consciousness of the Montenegrins is also "strengthened by some objects from the Montenegrin popular culture that originated in the minds of the people", and among them are the Montenegrin cap and the Montenegrin ceremonial costume. Vlahović repeats the widely disseminated concep that both the costume and hat were introduced by the bishop and ruler Petar II Petrović Njegoš, and the hat was a mark of the Serbian identity of the leaders to whom they were given by the ruler. Since the costume is a Serbian symbol per se, it carried an important national message. The Montenegrin ceremonial costume includes as its three parts the red waistcoat, the blue pants, and the white knee socks: all symbolising "the Serbian tricolour flag by which the Montenegrins have undoubtedly confirmed their ethnic being since the times of Dušan until the present day" (Vlahovic 1995). The same is said about the coat of arms on the flag of Montenegro, said to be symbols of the continuation of the Serbian state and cultural tradition. Development of the costume as national symbol means placing the whole existence and history of Montenegro as successor of the Serbian Nemanjić and Kosovo tradition. The coat of arms of the Crnojevic (the dynasty that ruled Montenegro after 1455 until 1528 while Ottoman empire was settling in the region and Zeta was incorporated into the Empire in 1499), and of medieval Serbia, whose tradition was preserved and guarded by the Montenegrins under the Turks, had a two-headed eagle over whose breast a lion on the plate was added in the 18th century as the symbol of Petrović Njegoš family. In 17th century, Montenegrins liberated themselves and started to demonstrate their national consciousness as Serbian people. It was possible to express it freely since only Old Montenegrin's highlands were free from the Ottoman rule.

Vlahović presents all the arguments of the Serbian historiography and ethnology on the national issue of the Montenegrins - that 
genealogically, ethnically, historically and culturally they share the same path as Serbian people, they show Serbian consciousness and therefore, they should be considered Serbs, not Montenegrins in a national sense. In this scientific framework, independent Montenegro would have a reason to exist as far as it continues the Serbian nationhood. This scientific approach sees Montenegrins as ethnic Serbs who live in a geographic region of Montenegro, part of otherwise politically and ethnically Serbian territories. The spirit is embodied in the cultural specifics of Montenegro and one example of it is the Montenegrin costume and hat, genealogically and symbolically bound to the Serbian state and the Serbian national idea.

All the symbols applied in the embroidery of the Montenegrin hat are interpreted in this respect. If it is the cross (the so called krtsac, which is the battle flag of the Montenegrins), it would be related to the Orthodox faith. Strong ties with Serbian-hood are illustrated by interpretation of another symbol: a cross with four "C"-s (the Cyrillic letter for "S"). There are two popular explanations of this symbol as abbreviation. The first is the above mentioned meaning as Samo sloga Srbina spašava and the other, which is met only in popular interpretations, is Sveti Sava - Srpska Slava ('Saint Sava $^{8}$ - Serbian feast'). The first phrase is related to the idea of unification of all Serbs on the Balkans, ideally under the leadership of Serbia as a Piedmont on the Balkans. The second leads to the important role of the most prominent saint (being also a member of the Nemanjić dynasty), namely Saint Sava (1219-1233) - founder of the "unified body" of the Serbian church on the Balkans. The celebration of all rituals in the calendar cycle of holidays within the Serbian Orthodox Church is called Svetosavlje ('Saint-Savianship'). The existence of such symbols should also contribute to the thesis that Montenegrins are part of the Serbian nation and what makes Montenegrins different when compared to the Serbs is their independent existence in Old Montenegro for a long period of the Ottoman rule in other parts of the Peninsula. For authors such as Vujović (Vujovic 1987) this contributed to development of a particular Montenegrin national consciousness, while most authors of the historian school think that the Montenegrin identity was never separate from the Serbian national identity (Čorović 1989; see also Ćirković 1981). It is natural that the Montenegrins then apply, explore and "import" concepts, ideas, and cultural artefacts 
from other Serbian lands. That is why Mirko Barjaktarović in his article "On the origin and time of the appearance of the "Montenegrin" Hat" put Montenegrin in brackets, to show that the costume is not a pure Montenegrin national phenomenon but is rather a definition to mark an ethnographic category.

All the national phenomena - myths about descent, language, religion, and the costume as a syncretism of the ethno-culture - are viewed as proof that Montenegrins are ethnic Serbs. The thesis about the costume is proven on the basis of early medieval times, ethnographic records in written sources, and official documents of the Petrović dynasty.

\section{Montenegrin Costume as a Symbol of the Montenegrin National Consciousness and Its Development}

The same sources lead to conclusions presented in studies published in Montenegro at the end of the 1970s and beginning of the 1960s and which stand behind the thesis that Montenegrins are an independent nation, separate in terms of ethnicity and history from the Serbian nation. Although this thesis has its roots in the public space and debates in Montenegro since the time of its unification with Serbia and inclusion in the Kingdom of Serbs, Croats and Slovenes in 1918, during the 1960s the dominant opinion about the genesis and meaning of the costume is questioned scientifically. The cornerstone of Montenegrin ethnology in regard to the Montenegrin costume and hat is the detailed research and publication on Montenegrin costume and guns by Risto Dragicevic (Dragiceević 1962). Without touching the issue of the national symbolism of the Montenegrin costume, the author sees its development in close relation to the historical development that Montenegro itself went through. Dragicević argues that it was not Njegoš who invented the costume, but that it had been developing since medieval Zeta (part of today's Montenegro that is considered to be its predecessor). Its development and symbolism is placed first in the 13 th and 14th centuries and it has been influenced by the ruling insignia of the contemporary Nemanjić dynasty, which on the other hand was influenced by Byzantium (Dragićević 1962: 25). The Montenegrin population migrated from Zeta to the highlands of Montenegro around Cetinje and that is how the costume and all other cultural 
relicts "migrated" too. The symbolism of the costume is a particular embodiment of that specific development of Old Montenegro as a free land. Old Montenegro was free from the Ottoman Empire; otherwise it would have been impossible to wear such clothes from the 16th to 18th. Non-Muslims, or raja, did not have the right to wear clothes similar in colour or model with those of Muslims. Green, red, and white were the colours of the sultan and the ruling officials in general.

In the lands of Old Montenegro where the costume was worn, these rules and regulations were not in force simply because in these territories the Ottoman governance did not exist, i.e., they were free. (Dragićević 1962: 33-34) Dragićević argues against the statement that until the Congress of Berlin (1978), where Montenegro was recognized internationally, Montenegro was part of the Ottoman Empire, claiming that Montenegrin men and women wore their richly coloured dress, since there was no Turks government (Dragicević 1962: 34-35). As far as the costume's old existence is concerned, Dragićević analyses different literature and visual sources such as historical archives from the 17th century and finds different clothes (corret, dolama, caps, and ornaments that were part of the Montenegrin costume) and the cornerstone of the thesis is an aquarelle picture in which parts of the luxurious Montenegrin costume are recorded in colour (Dragićević 1962: 42-43). Since it was a national symbol of independent Montenegro, the costume was distributed to other territories once they got their independence. Parallel to strengthening the influence of Cetinje over the neighbouring tribes, and beginning with the rule of Mitroplitan Danilo and particularly after Highlands $(B r d a)$, they were united with Old Montenegro in 1796 and the Montenegrin national costume was accepted in these regions as well (Dragicević 1962: 32-33). The democratization of power into the hand of tribes in the 15th through 17th centuries made the costume of the Crnojevic dynasty into a symbol of the free Montenegrins, since there was no central rule any more. Logically, the symbols were kept by the unifying figures of the "Metropolitan" in Cetinje, where the coat of arms and other insignia were kept. Once a particular territory of a given tribe was free from Ottoman governance, the costume was distributed there as well. This study raises three issues opposing the dominating view - origin, meaning, and dissemination of the Montenegrin costume. 
The publications of Zorica Mrvaljević, whose $\mathrm{PhD}$ thesis was devoted to the Montenegrin hat, are pretty much based on the sources revealed by Risto Dragićević. Her conclusions, however, go a few steps further in regard to viewing the development of the festive costume and Montenegrin hat as phenomena interrelated with and a result of the specific developments in the Montenegrin politics and history. This may be the only implicit thesis in the Montenegrin ethnography on dress that can be put within the pro-Montenegrin context of interpretation of Montenegrin history and culture, according to which the independent Montenegrin nation and the Montenegrin costume as symbol of Montenegrin statehood from the Middle ages continues to develop further and flourishes during the time of political success in the time of the Petrović-Njegoš dynasty. Through the history of the genesis and development of the costume and its hat one can trace Montenegrin history. The main pillars in the works of Mrvaljević are two. First, critic of the fundamental Serbian and Yugoslav statement that the Montenegrin costume is finally constituted by Petar II Njegoš is an expression of and relation to other processes in the state building project - the national project for Serbian state renewal, codification of rules, stabilization of the state officials, etc. While in her earlier work "Montenegrin men's hat", she shared the view that the hat's development can be traced back and proved since the medieval time of the proto-Montenegrin state Zeta (Radulovic 1976), in the monographic publication that appeared during the period of affirmation of Montenegrin identity, history, and culture (Mrvaljević 2006), she considers the costume to incorporate motives from an earlier period influenced by the Duklja ${ }^{9}$ tradition with cultural layers and symbols of Illyrian, Greek, Roman and later-Slavic origin (Mrvaljević 2006: 20). Since the 1980s, scholars and researchers who write about the emergence of the Montenegrin nation and existence of Montenegrins as a particular ethnic group in early periods of history claim that Duklja was the first Montenegrin state and its population was different from the Slavs, a mixture of autochthonous and migrated populations (Kulisić 1980, Rotković 1992). Interpretations of written sources on the Duklja people and rulers, mentioning the ethnic composition of the state, and the issue whether Dukljans are ethnically Serbs, Croats or a particular ethnic group is one of the most crucial issue in the historiography on Montenegrin history and divides the 
scientists into ones who think that Duklja is a state inhabited by Serbian people (Vukćević 1981, Vukćević 1981a, Čorović 1989) and those who think that Dukljans means a specific ethnic entity (Kulisić 1980, Nikčević 1987) equal to the neighbouring ethnic entities of Serbs, Croats, Zahumljans, etc. Thus, people of Duklja, who inhabited the territories from a time before the Slavs migration, are forefathers of Zeta people, later known as Montenegrins. The "antiquity" (Anderson 2006) of the Montenegrin nation, formed on an ethnic substrate that preceded the Serbian one, is proven by its relation to the territory and people of Duklja. The research and analysis by Mrvaljević should be interpreted in this context as well.

Mrvaljević provides sources and archive data that prove that the costume appeared not at the time of Petar I and Petar II Njegoš, but in the Middle Ages, when it was official for the Crnojević ${ }^{\mathbf{1 0}}$ dynasty and aristocrats. The dynasty that governed Zeta in 15th century as a state separate from Serbia had its own insignia and identity that are further kept and maintained in Old Montenegro via the official and popular costumes. According to Mrvaljević, it was at the time of Stefan Crnojevic that it spread and was recognized and supported by the Venetian Republic. It was influenced much more by the West than by the neighbouring lands of the Ottoman Empire. After analysing the social and economic conditions in the state, the author concludes that the ruling dynasty had its own costume and symbols of self-identity and independence, fact being "that Crnojevic created their particular, luxurious, artistically refined style of dressing, similar to the costume known as Montenegrin today" (Mrvaljević 2006: 42). As a symbol of the old Montenegrin statehood, the costume was a significant symbol in the struggle for freedom, along with the other cultural and historical elements, inherited by the Crnojevic state: the coat of arms and the flag, the monastery that embodied the theocracy in the state, the relations with other Western states which influenced the costume's development, and others. Crnojević moved their capital to Cetinje and gradually the state power was somehow de-centralized and this also applies to the rulers' relations with the lay-people. The author supposes that this democratization of power in terms of policies meant that every single Montenegrin became an equal participant in decision-making and in the fight, while in terms of culture a larger production and 
use of the Montenegrin woollen costume took place later, in the time of struggle for survival (Mrvaljević 2006: 44).

The development of the costume was thus as follows. First, it was worn only by the Crnojevic dynasty and the highest aristocrats but later, when the state got weaker, prosperous people also started to wear it, especially outstanding fighters; after the fall of the Crnojevic dynasty it "became one of the symbols of autochthony and independence of Montenegro in their struggle for survival" (Mrvaljevic 2006: 189). This leads to the conclusion that the costume itself presents a symbol of the Montenegrin identity centuries before the Petrović-Njegoš dynasty, as expression of the idea for self-identity, homogenization (of the Montenegrin consciousness over other territories). It was not that the costume was influenced by Bay of Kotor or other Serbian territories, nor it was influenced by the Serbian national idea. It was vice versa - the festive costume as symbol of the Montenegrin identity was disseminated in territories outside Old Montenegro. At the time epic literature was flourishing, including myths and legends which particularly cherished the Crnojević tradition (Mrvaljević 2006: 68), while the Kosovo legend and epic were not rooted in these territories.

As far as the Montenegrin hat is concerned, in an earlier publication (Radulović 1976) the same author developed a similar thesis about the genesis of the cap and sees the function of the hat as a national symbol with great importance for public, festive, daily life, and as a symbol of honour and dignity. The freedom of Montenegro was proven by the costume and its hat, since it was permissible to wear it. A key disputable issue for that work is the interpretation of the four S-s on the hat, not as S, but as four tinders, and as rulers' symbols inherited from Byzantium. The author provides data that hats with this embroidery were introduced forcedly after the unification of Serbia and Montenegro in 1918 (Radulovic 1976: 112-113). This interpretation leads to another corner stone in the historiography on Montenegrins past: namely, that Montenegro was unified not by its political will with Serbia after the end of WWI, but was forcedly annexed with the support of Serbian troops (Rastoder 2004, Rastoder 2006).

In this context, critique of the most frequent interpretation of this symbol, "which is unfortunately unscientific", as the representa- 
tion of the four "S" letters (in Cyrillic), meaning "only accord saves the Serbs" (Samo sloga Srbina spašava) is expressed (Mrvaljević 2006:145). According to the popular interpretation, which I accounted within my field research in both Serbia and Montenegro, this symbol of Serb-hood and unification is old and inherited by the old Serbian tradition, a thesis shared in the publications with a pro-Serbian view (Vlahović \& Miodrag 1953, Vlahović \& Petar 1995, Barjaktarović 1979). However, according to the new school in Montenegrin historiography and ethnology, this interpretation is popular but not scientific. There are even misinterpretations since the sign has nothing in common with Serbian symbolism but is rather a universal heraldic symbol. According to the recently produced Historical lexicon of Montenegro:

This "interpretation" of the four C symbols is, however, merely a mythological invention of Great Serbia propaganda. In fact, this Serbian national seal does not represent four $C$ letters but rather, as stated in the Serbian constitution, was originally designed to represent four ognjilo, kresivo (curved pieces of steel used with flint to strike a spark). Nonetheless, this myth is used today by quasi-historians and charlatans as "proof" that Montenegrins are of Serbian origin! (Istorijski Leksikon Crne Gore)

The research conclusions and publications of Zorica Mrvaljević argue with the dominating approach of pro-Serbian historiography and lead to the conclusion that the Montenegrin state and state symbols/people/cultural identity have their own development, different from the Serbian. This approach and conclusions should be put in the context of the Montenegrin social sciences and humanities developments after the 1970s and 1980s when the political and social climate in Yugoslavia had stimulated the development of research on national developments in each republic after the constitutional changes with which the level of responsibly and decisions was shifted to the republican level (Bertsch 1977, Ramet 1992). In the 1970s the Central Committee of the League of Communists in Montenegro reached a decision to do a Marxist study on the Montenegrin question (Dulovic 2009: 117). This was also the period of building of national cultural and educational institutions in Montenegro, the founding of the first universities and national 
media (Rastoder 2006). Two milestone scholar publications were the book of Savo Brkovic "On the Establishment and Development of the Montenegrin Nation" (Brković 1974) and the research of Špiro Kulišić "On the Ethno-genesis of the Montenegrins" (Kulišić 1980). What unites the publications is the conclusion that the Montenegrin people are ethnically different from the Serbian nation and they inherit a specific and older population that had lived on these territories (Zećani or Dukljani). Their development was different from that of the neighbours and this is seen in physical type, in language, in traditional culture, especially in the older social organization and in a number of specific customs, including the costume.

The terms Serb and Serbdom, as they in general ware used to mobilize the Orthodox population, as well as the existence of the name Serb in 18th and 19th century Montenegro meant "Orthodox Christian". In the pro-Montenegrin historiography the historical sources from the medieval chronicles are interpreted as proving the existence and development of the Montenegrin state-hood with the traditions and people in Duklja and Zeta. The ethnography of the costume and the quoted publications were aimed at pointing out that Montenegrin ethnicity and nationhood developed on the basis of a mixture of Slav and autochthonous pre-Slav populations (Roman, Illyrian, Vlach). Moreover, the Montenegrin nation had attained its statehood and identity long before the Serbian one. According to the historical sources interpreted by Mrvaljević, Montenegrin state development had a weak interrelation with the Serbian state/people, and a much stronger influence by the Western (Venetian) and Byzantium cultures. Mrvaljević excerpts the roots of the Montenegrin costume from the same period, by interpreting archives, proving the import and export of goods for dress and descriptions of insignia of the dynasties of Crnojević. The dress of the aristocrats in the state of Crnojevic and the state dynasty symbols appear to be fundamentally of a number of elements in the traditional Montenegrin costume: $d u s ̌ a n k a$,jelek jacket, džmadan, and they are results of experienced cultural interrelations with other neighbouring cultures and states, but to a lesser degree with the Serbian state tradition. The author questions, but does not reject completely, the thesis for the symbolic interpretation of the Montenegrin costume as symbol of the Serbianhood (Kosovo, Dušan, Nemanjić traditions) promoted by Njegoš and the three main colours of the costume that are believed to be the 
colours of the Serbian flag. At that time the Montenegrin dynasty was hugely influenced by the idea of unification of all South Slavs and the example of such unification can be observed in the Nemanjić state. The pro-Montenegrin historiography promotes the statement that the Montenegrin rulers, particularly Njegoš and King Nikola thought themselves to be Serbian rulers and the population to consider itself as both Serbians and Montenegrins, since the dynasty had the ambition to unite all Serbs on the Balkans under their rule. This was the time when the development of the Kosovo myth among Montenegrins was stimulated and pro-Serbian interpretations of the embroidery started to circulate amongst people. Montenegro's particular development differed from that which occurred throughout Serbian lands and led to the formation of a particular and independent ethnic entity (the ancestor of Montenegrins) and its legitimacy can be traced and demonstrated with the occurrence and constitution of the national costume.

\section{Conclusion}

The scientific opinion that Montenegrins are a separate nation is related to all "historical myths" of a nation: its antiquity, its originality and contribution to the development of culture and civilization and this is traces by the official costume development. On the other hand, the older view that develops in the social sciences tradition since Cvijic onwards is that the Montenegrin population and its ethno-culture is Serbian by ethnicity, sharing ethno-cultural characteristics with all Serbs on the Balkans (language, religion, national myths and heroes, etc.), including the three-coloured flag and Nemanjić tradition presented in the costume's origin and meaning.

The discussion about the official costume should be placed in the context of the interpretation of the Montenegrin issue in Yugoslav historiography throughout its development. Serbian historiography views Old Montenegro as a successor of the Serbian state tradition and Montenegrins as part of the Serbian national corpus, while Montenegrin ethnologists and the new school of history in Montenegro today view Montenegrins as a separate nation with specific development in the field of history, ethno-culture, and genesis. The two main scientific interpretations of the national costume show that the Montenegrin costume has a special place as symbol of the 
chain of all nation-related phenomena - the nation-state and its leaders, national symbols, historical pasts and myths of descent. The costume is one of the main symbols of Montenegro and is considered to be an ethno-cultural marker for both Montenegrins and outsiders in a similar manner as the other Montenegrin symbols (figures such as Petar II Njegoš, his literary work "Mountain Wreath", the national flag and coat of arms, etc.) are all objects of interpretation in the light of identity and ethnicity. The costume communicates and constitutes ethnic and national identities of the people who create and wear it. Furthermore, it is seen as a symptom and product of the historical and cultural development of the Montenegrins themselves and a true national embodiment. Its interpretations are a matter of cultural politics for its interpreters and readers and in today's debates on Montenegrin identity it continues to be such.

\section{Notes}

${ }^{1}$ Article 1 of The Constitution of Montenegro adopted on 17 October 2007, translated into English on http://www.comparativeconstitutionsproject. org/files/Montenegro_2007.pdf

2 The last two census data show that the orthodox population had mostly identified as Montenegrins before 1992 (almost 90\% of the population), while the same community is today divided between two identities: Montenegrin and Serbian, Montenegrins being $43.16 \%$ and Serbs being $31.99 \%$ of the total population. See details in Yearbook 2000: 248.

${ }^{3}$ One of the Montenegrin Prince-Bishops from Petrović dynasty, his rule turned the country from a theocracy into a secular state. He is considered as one of the most famous poets writing in Serbian language, the most notable works include "The Mountain Wreath", the "Light of Microcosm", "Serbian Mirror", and "False Tsar Stephen the Little".

${ }^{4} \mathrm{http} / / / c r n o g o r s k a n o s n j a . c o m /$ (No longer accessible).

${ }^{5}$ Contemporary Montenegro comprises of several regions that are clearly distinguished first and foremost by their different historical and cultural development throughout history - a Northern part of Sandžak, which was part of the Ottoman Empire will the beginning of XX century, a central part which includes Old Montenegro and Seven Highlands that had lived under the tribe political and territorial system and South or Coastal Area with Bay of Kotor that became part of Montenegro only after 1945. 
${ }^{6}$ Dušan the Mighty, King of Serbia (1331-46) and "Emperor of the Serbs, Greeks, and Albanians" (1346-55), considered as the most successful ruler of medieval Serbia.

${ }^{7}$ Miloš Obilić (Serbian Cyrillic: Милош Обилић) one of the warriors of Prince Lazar and assassin of the Ottoman sultan Murad I at the battle of Kosovo (1389), with which he became part of the Kosovo myth. Within half a century after the event, the name is mentioned in writing in Serbian and Greek and he also became a popular and major figure in Serbian epic poetry, in which he is elevated to the level of the most noble national hero of medieval Serbian folklore, and a a saint of the Serbian Orthodox Church.

${ }^{8}$ B. $1175 / 6-$ d. 1233 , one of the most prominent Serbian saints and the first Serbian Archbishop, founder of the episcopates of the Serbian Orthodox Church, son of Stefan Nemanja, ruler and founder of the medieval Serbian state.

${ }^{9}$ Duklja, Diokletija or Doclea was a medieval state first encompassing territories of present-day Montenegro (Zeta River, Lake Scutari and the Bay of Kotor) and bordering with Travunia at Kotor. Duklja was at first a vassal of the Eastern Roman Empire until it won its independence in the mid-11th century, ruled by the House of Vojislav (Vojislavljević), who is considered to be the founder of the first Montenegrin dynasty. After a large fall, Doclea was incorporated into the Serbian state, where it remained until the fall of the Serbian emperor, tsar Stefan Uroš IV Dušan, when it regained independence, changing its name to Zeta.

${ }^{10}$ A royal family that ruled in Zeta throughout the 15th century (14271496), they resisted the Ottoman invasion. It moved the capital to Žabljak, and later on in Cetinje. Crnojevics are known as the introducers of the first printing press in southern Europe and in printing the first books in the region.

\section{References}

Anderson, Benedict 2006. Imagined Communities. London \& New York: Verso.

Barjaktarović, Mirko 1979. Porjeklo i vreme nastajanje "Crnogorske" nošnje [Origin and time of appearance of the "Montenegrin" Hat']. Glasnik Etnografskog muzeja, 43. Belgrad.

Barjaktarović, Mirko 1987. Vuk Karadźić o nošnji Crnogoraca [Vuk Karadźić on the costume of Montenegrins]. Naucni skupovi 16. Glasnik odjeljenja umjetnosti Crnogorske akademije nauka i umjetnosti, 5. Titograd. 
Bertsch, Gary K. 1977. Ethnicity and Politics in Socialist Yugoslavia. Annals of the American Academy of Political and Social Science, Vol. 433. Ethnic Conflict in the World Today (Sep., 1977), pp. 88-99.

Bieber, Florian (ed.) 2003. Montenegro in Transition. Baden-Baden: Nomos.

Brković, Savo 1974. O postanku i razvoju Crnogorske Nacije [On the establishment and development of the Montenegrin nation]. Titograd: Graficki Zavod.

Cvijić, Jovan 1922. Balkansko poluostrovo I južnoslovesnke zemlje, I. Belgrade.

Ćirković, Sima (ed.). 1981. Istorija srpskog naroda I-X: Od doseljavanja na Balkan do 1918. godine [History of Serbian Peoples]. Beograd: Srpska književna zadruga.

Čorović, Vladimir 1989. Istorija Srba [History of the Serbs]. Belgrade: BIGZ.

Delari, Anri 2003. Crna Gora [Montenegro]. Podgorica: CiD.

Djonović, Nikola 1935. Rad i karakter Crnogoraca [Occupation and Character of the Montenegrins]. Beograd: izdavacko i knjizarsko preduzece Geca.

Dragićević, Risto 1962. Nekoljiko arhivskih podataka o Crnogorskoj narodnoj nošnji i Crnogorskom oruzju [Some archive data on Montenegrin national costume and Montenegrin gun]. Glasnik Etnografskog muzeja na Cetinju, pp. 23-55.

Dulović, Vladimir 2009. Montenegrin Historiography and Nation-Building 1948-1989. Sasa Nedeljković (ed.). The Challenges of Contemporary Montenegrin Identity. Anthropological Research of the Transformation of Montenegrin Identity Formula since World War Two. Kruševac: Baštinik, pp. 107-143.

Durković-Jakšić, Ljubomir 1953. Njegoševa nošnja [The costume of Njegoš]. Zbornik radova Etnografskog muzeja u Beogradu. 1901-1951. Belgrade, pp.105-106.

Enciklopedija Crne Gore [Encyclopedia of Montenegro] 1996. Podgorica: Aimpress.

Erdeljanović, Jovan 1907. Kuči - pleme u Crnoj Gori [Kuci - tribe in Montenegro]. Srpski Etnografski Zbornik, VIII, Beograd.

Erdeljanović, Jovan 1911. Postanak plemena Pipera [Origin of the Piper Tribe]. Srpski Etnografski Zbornik, 17. Beograd: Državna stamparija Kraljevine Srbije. 
Erdeljanović, Jovan 1920. Neke crte u formiranju plemena kod dinarskih Srba [Some features in establishment of the tribes among Dinar Serbs]. Glasnik Etnografskog društva u Beogradu, V. Beograd.

Erdeljanović, Jovan 1978. Stara Crna Gora: etnička prošlost $i$ formiranje crnogorskih plemena: sa 7 fotografija i 5 karata u prilogu i 3 skice u tekstu [Old Montenegro: ethnic past and formation of the Montenegrin tribes; with 7 pictures and 5 maps in the annex and 3 drawings in the text]. Beograd: Slovo ljubve.

Halpern, Joel M. \& Hammel, E. A. 1969. Observations on the Intellectual History of Ethnology and Other Social Sciences in Yugoslavia. Comparative Studies in Society and History, Vol. 11 (1) (Jan., 1969), pp. 17-26.

Hobsbowm, Eric 2008. Nations and Nationalism since 1780: Programme, Myth, Reality. Cambridge: Cambridge University Press.

Istorijski Leksikon Crne Gore [Historical Lexicon of Montenegro] 2006. I-IV. Podgorica: Vijesti.

Istorija Crne Gore [History of Montenegro] 1975. III: I. Titograd: Redakcija za istoriju Crne Gore.

Jovićević, Andrija 1911. Rijecka nahija (u Crnoj Gori) [The nahija Riječka (in Montenegro)]. Srpski etnografski zbornik, 15. Beograd, pp. 385-832.

Jovićević, Andrija 1903. 'Crna Gora (Katunska, Riječka, Crmnička, Lešanska i Bjelopavlićska nahija): narodni život i običaji' [Montenegro (the nahijas Katunska, Riječka, Crmnička, Lešanska and Bjelopavlićska): folks' life and customs]. Zbornik za narodni život i običaje Južnih Slavena, VIII. Jugoslavenska akademija znanosti i umjetnosti.

Kale, Jadran 2009. Prehistory of the Term "Folk Costume". Etnološka iztraživanja /Ethnological Researches, Vol. 1 (14) (December 2009), pp. 85-99.

Karadžić, Vuk Stefanović 1922. Crna Gora i Boka Kotorska [Montenegro and Bay of Kotor]. Srpska književna zadruga, XXIV:161. Beograd: Novi Sad, Štamparsko poduzeće "Zastava".

Karadžić, Vuk Stefanović 1972 [1837]. Crna Gora i Crnogorci [Montenegro and the Montenegrins]. Beograd: Nolit.

Kulisić, Špiro 1980. O etnogenezi Crnogoraca [On the ethno-genesis of the Montenegrins]. Titograd: Pobjeda. 
Malesevic, Sinisa \& Uzelac, Gordana 2007. A nation-state without the nation? The trajectories of nation-formation in Montenegro. Nations and Nationalism, 13 (4) (October 2007), pp. 695-716.

Mantegaca, Viko 2001. Crna Gora [Montenegro]. Podgorica: CiD.

Medaković, Milorad 1860. Život i običaji Crnogoraca [Life and customs of the Montenegrins]. Novi sad: Matica Srpska.

Mrvaljević, Zorica 1988. Narodna nošnja Crne Gore [National costume of Montenegro]. Zagreb: Kulturno prostvjetni sabor Hrvatske.

Mrvaljević, Zorica 2006. Crnogorka nardona nosnja [The National Costume of Montenegro]. Podgorcia: Muzej i galerije Podgorice.

Nakičenović, Sava 1982. Boka: antropogeografska studija [Boka: Anthropogeographical study]. Herceg novi: Arhiv.

Nenadović, Ljubomir 1929. O Crnogorcima, pisma sa Cetinja 1878. godine [About the Montenegrins, letters from Cetinje in 1878]. Beograd: Stamparija "Sv. Sava".

Nenadović, Ljubomir 1950 [1907]. Pisma iz Italije [Letters from Italy]. Beograd: Jugoslovenska knjiga.

Nikčević, Vojislav 1987. O Postanku Etnonima Dukljani, Zećani, Crnogorci [On the origins of the ethnonims Dukljani, Zećani, Crnogorci]. Cetinje.

Pavlović, Srdja 2003. Literature, Social Poetics and Identity Construction in Montenegro. International Journal of Politics, Culture and Society, Vol. 17 (1) (Fall 2003), pp.131-165.

Pavlović, Srdja 2003a. Who are Montenegrins? Statehood, Identity and Civil Society. Florian Bieber (ed.). Montenegro in Transition. Problems of Identity and Statehood. Baden-Baden: Nomos Verlagsgesellschaft.

Radojevic, Danilo 1969. Ukarsi na kapi crnogorskoj [Decoration on the Montenegrin Hat]. Pobjeda. Titograd.

Radulović, Zorica 1976. Crnogorska muška kapa [The Montenegrin man's cap]. Glasnik Cetinjskih muzeja, 1. Cetinje, pp. 103-118.

Rastoder, Šerbo 2003. A short review of the history of Montenegro. Bieber, Florian (ed.). Montenegro in Transition: Problems of Identity and Statehood. Baden-Baden: Nomos Verlagsgesellschaft, pp. 107-137.

Rastoder, Šerbo 2004. Crna Gora u egzilu 1918-1925 [Montenegro in exile 1918-1925], I-II. Podgorica: Istorijski institut Crne Gore/Almanah. 
Rastoder, Šerbo \& Andrijašević, Živko 2006. Istorija Crne Gore: Od Najstarijih Vremena do 2003 [History of Montenegro: from ancient times to 2003]. Podgorica: Centar za Iseljenike Crne Gore.

Ramet, Sabrina Petra 1992. Nationalism and Federalism in Yugoslavia. 1962-1991. 2nd ed. Bloomington: Indiana University Press.

Pišev, Marko 2009. Politička etnografija i srpska intelektualna elita u vreme stvaranja Ju-goslavije 1914-1919. Istorijski pregled [Political Ethnography and Serb Intellectual Elite in the Era of the Creation of Yugoslavia 1914-1919. A Historical Overview]. Etnološko-antropoloske svezke, 14, pp. 43-77.

Rotković, Radoslav 1992. Odakle su dosli preci Crnogoraca [Where did the ancestors of the Montenegrins come from]. Podgorica: Matica Crnogorska.

Rovinski, Pavel Apolonovic 1998. Etnografija Crne Gore [Ethnography of Montenegro], 1-2. Podgorica: CiD

Schwarz, Bernhard 1876. Montenegro: schilderung einer Reise durch das Innere nebst Entwurf einer Geographie des Landes. Leipzig: Verlang Eduard Baldamus.

Smith, Anthony D. 1996. Culture, Community and Territory: The Politics of Ethnicity and Nationalism. International Affairs (Royal Institute of International Affairs 1944-), Vol. 72 (3), Ethnicity and International Relations (Jul., 1996), pp. 445-458.

http://www.jstor.org/stable/2625550

Šobajć, Petar 1923. Bjelopavlići i Pješivci. Srpski etnografski zbornik, 27. Beograd: Srpska kraljevska akademija.

Stivenson, Frensis S. 2001. Istorija Crne Gore [History of Montenegro]. Podgorica: CiD, 2001

Svatek, Frantisek Jan. 2000. Crna Gora i Skadar [Montenegro and Skadar]. Podgorica: CiD.

Vlahović, Miodrag 1953. O najstarijoj kapi kod Jugoslovena [On the oldest hat among the Yugoslavs]. Zbornik radova Etnografskog muzeja u Beogadu 1901-1951. Belgrade, p. 151.

Vlahović, Patar 1990. Kosovska legenda u svetlu usmene crnogorske tradicije [The Kosovo legend in the light of the oral Montenegrin tradition]. Naučni skupovi, 21, CANU, Odeljenje umetnosti. Titograd, p.211-218

Vlahović, Petar 1995 The Serbian Origins of the Montenegrins. The Serbian Question in the Balkans. Faculty of Geography, Univer- 
sity of Belgrade, 1995, pp 157-168.

http://www.rastko.org.yu/rastko-cg/povijest/vlahovic.html

Vujović, Dimitrije-Dimo 1987. Prilozi izučavanju crnogorskog nacionalnog pitanja [Contributions to the research of the Montenegrin national question]. Nikšić: Univerzitetska rijec.

Vukćević, Nikola 1981. Osurt na neka pitanja iz istorije Crne Gore [Review on some issues in the history of Montenegro]. Belgrade.

Vukćević, Nikola 1981a. Etničko porijeklo Crnogoraca [The ethnic origin of the Montenegrins]. Belgrade.

Vukmanović, Jovan 1952. Njegoševa nošnja [The costume of Njegoš]. Glasnik Etnografskog Instituta, 1(1-2), Beograd: Srpska akademija nauka i umetnosti, pp. 135-141.

Vukmanović, Jovan 1953. Nošnja i oruzije bokeljske mornarice [Costume and Guns of the Boka Flot]. Spomenik SANU, 5. Beograd: SANU.

Yearbook 2000 = Statistički godišnjak Republike Crne Gore 2000. Podgorica: Republički zavod za statistiku, 2000. 


\section{ELM Scholarly Press \\ SATOR 18}

http://dx.doi.org/10.7592/Sator.2017.18

\section{BALKAN AND BALTiCUM}

Current Studies in the Postsocialist Space

Edited by

Ekaterina Anastasova and Mare Kõiva

Tartu 2017 
Editors and compilers: Ekaterina Anastasova, Mare Kõiva Series "Sator" editor: Mare Kõiva

Language editors: Liisa Vesik, Lii Liin

Cover photo: Jaak Kikas, 2017 "Autumn in Tartu"

International committee

Tiiu Jaago (Tartu University); Reet Hiiemäe (Estonian Literary Museum); Mare Kalda (Estonian Literary Museum); Tarmo Kulmar (Tartu University); Nikolay Kuznetsov (Estonian Literary Museum); Aado Lintrop (Estonian Literary Museum); Emily Lyle (School of Scottish Studies in Edinburgh); Mirjam Mencej (Ljubljana University); Jonathan Roper (Tartu University); Marju Kõivupuu (Tallinn University); Ülo Valk (Tartu University); Tatjana Vladõkina (Institute of Udmurtian History, Language and Literarture, Izhkar); Irina Vinokurova (Institute of Karelian History, Language and Literarture in Petroskoi); Ergo-Hart Västrik (Tartu University)

Supported by Estonian Academy of Sciences, Bulgarian Academy of Sciences, the Centre of Excellence in Estonian Studies (CEES, European Regional Development Fund) and is related to research projects IRG 22-5 (Estonian Research Council).

\section{$\boldsymbol{C} E \mathbf{E} \times \begin{aligned} & \text { Centre of excellence } \\ & \text { in Estonian Studies }\end{aligned}$}

Series "Sator. Artikleid usundi- ja kombeloost", 18 http://www.folklore.ee/rl/pubte/ee/sator/sator18/

ISSN 1736-0323 (online)

ISBN 978-9949-586-58-5 (printed)

ISBN 978-9949-586-61-5 (online) ISSN 1406-2011 (printed)

DOI: 10.7592/Sator.2017.18

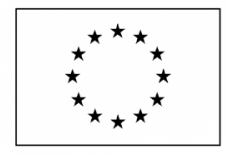

European Union European Regional Development Fund

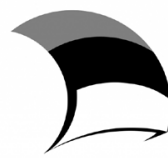

Investing in your future

\section{EUROPEAN UNION}

Regional Development Fund

Investing in your future
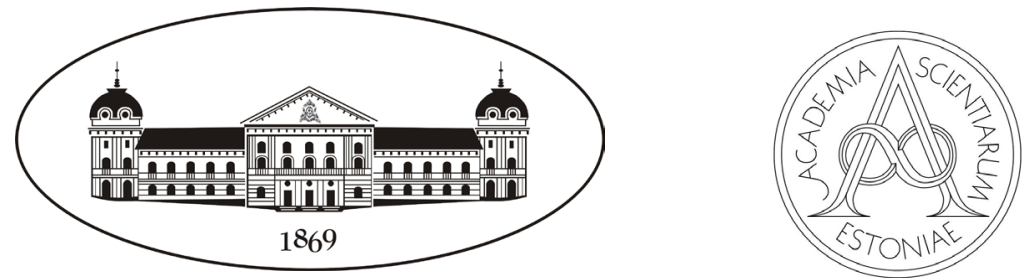


\section{Contents}

Preface

Mare Kõiva, Ekaterina Anastasova

CONSTRUCTING IDENTITY AND SOCIAL TIES

Ethnographic Studies on the Montenegrin

Festive Costume as a National Symbol

Sofiya Zahova

Social Ties of Bulgarians and Rudari in the Mediterranean Countries

Magdalena Slavkova

\section{RECASTING RELIGION AND \\ RELIGIOUS IDENTITY}

Contemporary Development of the Akyazili

Baba Tekke / St. Athanasius in Bulgaria

Yelis Erolova

Turkish Religious Identity in Bulgaria

94

in the Last Twenty-Four Years (1989-2013)

Mila Maeva

The Feast of Cyril and Methodius in Bessarabia and Crimea, Ukraine

Ekaterina Anastasova 
The Saints of Death in the Traditions

of the Balkan People

Rachko Popov

\section{CONSTRUCTING NEW SPIRITUALITY}

New Trends in the Study of Religion in Estonia -

Contemplations in the Grey Zone between

Religion and Science

Tõnno Jonuks

Constructing New Spirituality in Modernity -

the Case of the White Brotherhood in Bulgaria

Svetoslava Toncheva

Constructing Contemporary Periodical and

Occasional Rituals

Mare Kõiva

The Making of a Sacred Place:

221

An Example of Constructing Place Identity in the Contemporary Mentality

Reet Hiiemäe

\section{CHANGING TRADITIONS}

Bridge Over the Rainbow. Animal Burials and

Animal Cemeteries in Post-Socialist Estonia

Marju Kõivupuu

Simple Hide-and-seek at its Core: Play Features and the Game of Geocaching

Mare Kalda 